\title{
PENGEMBANGAN SISTEM IDENTIFIKASI KELUARGA MISKIN DI KABUPATEN TABANAN DENGAN MENGGUNAKAN METODE NAÏVE BAYES DALAM PENGENTASAN KEMISKINAN
}

\author{
I Wayan Supriana ${ }^{1}$, Putu Wida Gunawan ${ }^{2}$, IWK.Teja Sukmana ${ }^{3}$ \\ 1,2Program Studi Teknik Informatika, Universitas Dhyana Pura \\ ${ }^{3}$ Program Studi Manajemen, Universitas Dhyana Pura \\ Mangupura, Indonesia
}

Email: supriana@undhirabali.ac.id ${ }^{1}$, putu.wida@gmail.com² ${ }^{2}$ tejasukmana@yahoo.com²

\begin{abstract}
ABSTRAK
Kemiskinan adalah isu klasik yang masih terjadi di berbagai daerah di Indonesia termasuk Bali, khususnya daerah Tabanan yang memiliki tinggkat kemiskinan lebih tinggi dari tingkat kemiskinan provinsi. Jumlah keluarga miskin di Kabupaten Tabanan masih cukup tinggi meskipun Bali manjadi salah satu tujuan wisata mancanegara. Berbagai program prorakyat diterapkan untuk memutus rantai kemiskinan oleh pemerintah Kabupaten Tabanan, namun dalam prakteknya program kemiskinan seringkali salah sasaran. Dalam penelitian ini dilakukan penerapan pemanfaatan kemajuan teknologi informasai untuk mengidentifikasi sebuah keluarga, sistem yang dibangun akan menentukan tingkat kemiskinan keluarga berdasarkan indikator tingkat keluarga sejahtera. Metode identifikasi untuk mengetahui tingkat kemiskinan keluarga dengan menggunakan analisis Bayesian yaitu Naïve Bayes Classifier. Hasil yang diperoleh berdasarkan analisis dan implementasi bahwa sistem yang dibangun mampu mengidentifikasi tingkat kemiskinan keluarga sebesar $72 \%$ berdasarkan data uji yang digunakan, hal ini akan memudahkan program-program penanggulangan kemiskinan dapat disalurkan tepat sasaran sesuai rumah tangga miskin yang membutuhkan.
\end{abstract}

Kata kunci: Kemiskinan, Keluarga, Bayesian Analysis, Naïve Bayes Classifier

\begin{abstract}
Poverty is a classic issue that still occurs in various regions in Indonesia including Bali, especially Tabanan area which has higher poverty than the provincial poverty level. The number of poor families in Tabanan regency is still quite high even though Bali is one of the foreign tourist destinations. Various prorakyat programs are implemented to break the poverty chain by the Tabanan regency government, but in practice poverty programs are often misplaced. In this research, the use of information technology advancement to identify a family, the system built will determine the level of family poverty based on the indicators of family level prosperous. Identification method to know the level of family poverty by using Bayesian analysis is Naïve Bayes Classifier. The results obtained based on analysis and implementation that the system built is able to identify the family poverty rate of $72 \%$ based on the test data used, this will facilitate poverty reduction programs can be channeled on target according to poor households in need.
\end{abstract}

Keywords: Poverty, Family, Bayesian Analysis, Naïve Bayes Classifier

\section{PENDAHULUAN}

Kemiskinan merupakan permasalahan klasik yang masih terjadi di berbagai daerah di Indonesia khususnya Bali. Kemiskinan secara harfiah berasal dari kata "miskin". Makna kata miskin ini menurut Kamus Besar Bahasa Indonesia (KBBI) diartikan sebagai keadaan tidak berharta, serba kekurangan.
Sedangkan kemiskinan disebutkan sebagai situasi penduduk atau sebagian penduduk yang hanya dapat memenuhi makanan, pakaian dan perumahan yang sangat diperlukan untuk mempertahankan tingkat kehidupan yang minimum (Badan Pusat 
Statistik Provinsi Bali, 2014). Berdasarkan data Badan Pusat Statistik Provinsi Bali (Badan Pusat Statistik Bali, 2016 ), jumlah keluarga miskin di Bali pada bulan Maret tahun 2016 sebesar $4,25 \%$ yang tersebar di 9 Kabupaten/Kota. Tingkat kemiskinan di masing-masing kabupaten berbeda-beda seperti halnya di Kabupaten Tabanan memiliki tingkat kemiskinan sebesar 5,21\%, Kabupaten Badung memiliki tingkat kemiskinan sebesar 2,46\% dan lain sebagainya. Standar kemiskinan yang kenali oleh masyarakat untuk dapat digolongkan miskin ataupun tidak miskin telah mengalami pergeseran hal ini dikarenakan cakupan mengenai kemiskinan sendiri yang telah mengalami perubahan, seiring dengan semakin rumitnya indikator penyebab permasalahan kemiskinan tersebut (Badan Pusat Statistik Bali, 2016). Provinsi Bali manjadi tujuan obyek wisata mancanegara yang mestinya dapat mensejahterakan masyarakatnya secara merata, namun pada kenyataanya terdapat banyak rumah tanggan miskin (RTM) khususnya di daerah-daerah pedesaan.

Berbagai program prorakyat dilaksanakan untuk mengurangi tingkat kemiskinan dan merupakan prioritas utama dalam penanganan kemiskinan oleh pemerintah Daerah Provinsi Bali. Program pengentasan kemiskinan yang dilaksanakan diharapkan bermanfaat bagi masyarakat kurang mampu di Bali, seperti misalnya program bedah rumah dan program raskin. Program bedah rumah adalah program prorakyat yang memiliki tujuan untuk membantu rumah tangga miskin sehingga dapat mempunyai rumah yang layak huni, dan dapat memenuhi kebutuhan dasar secara minimal. Sementara program raskin (beras untuk rumah tangga miskin) adalah subsidi pangan berupa beras dengan sasaran rumah tangga yang memiliki penghasilan kecil sebagai program pemerintah dalam mendorong ketahanan pangan serta memberikan jaminan sosial pada keluarga miskin. (Badan Pusat Statistik Provinsi Bali, 2014).

Tabanan merupakan salah satu kabupaten yang memiliki tingkat kemisikinan lebih tinggi jika dibandingkan dengan tingkat kemiskinan Provinsi Bali, hal ini membuat pemerintah daerah Kabupaten Tabanan lebih serius mengatasi masalah kemiskinan dengan melaksanakan berbagai program bantuan bagi RTM. Pada saat ini pelaksanaan program-program untuk menanggulangi kemiskinan di Kabupaten Tabanan sering kali salah sasaran atau penerima bantuan bukan rumah tangga miskin tetapi termasuk golongan rumah tangga yang sudah mampu secara perekonomian. Fenomena ini terjadi karena tidak akuratnya identifikasi sebuah rumah tangga yang tergolong miskin atau tidak, adanya permainan pihak-pihak untuk mengambil keuntungan secara pribadi karena sistem pendataan rumah tangga tidak terkelola dan tidak terekem dengan baik. Pengajuan program-program pengentasan kemiskinan Kabupaten Tabanan dilalui dari pendataan rumah tangga untuk menentukan tingkat kemiskinan sebuah rumah tangga. Proses yang berjalan saat ini masih belum optimal dan terukur, sebab faktor-faktor penentuan tingkat kemiskinan tidak bersesuaian dengan data rumah tangga yang sudah dinilai atau dianalisis pada tahun-tahun sebelumnya. Terdapat indikasi kesesuaian antara data rumah tangga yang di analisis tahun-tahun sebelumnya dengan data rumah tangga yang akan di nilai berdasarkan faktor-faktor penilai yang digunakan. Data RTM yang tidak baik akan berdampak pada tahap berikutnya yaitu proses pengajuan daftar calon penerima bantuan program pengentasan kemiskinan ke pemerintah daerah, RTM mana yang sifatnya segera di ajukan dan yang tidak sehingga bantuan dapat disalurkan sesuai dengan kebutuhan dari RTM.

Berdasarkan kondisi tersebut maka melalui penelitian ini dilakukan penerapan pemanfaat kemajuan teknologi informasi berupa sistem aplikasi yang dapat membantu untuk mengidentifikasi kemiskinan sebuah rumah tangga berdasarkan indikator tingkat keluarga sejahtera. Metode identifikasi untuk mengetahui tingkat kemiskinan dari sebuah rumah tangga menggunakan Bayesian Analysis yang dalam hal ini adalah Naïve Bayes Classifier.

Naïve Bayes Classifier adalah sebuah metode identifikasi yang bersumber pada terorema Bayes. Metode identifikasi dengan menggunakan metode probabilistik dan statistika yang di kemukakan oleh ilmuwan Inggris Thomas Bayes, yaitu 
memprediksi peluang di masa yang akan datang berdasarkan referensi kejadian waktu sebelumnya kemudian dikenal sebagai Teorema Bayes. Kriteria dari Naïve Bayes Classifier adalah hipotesis yang sangat kuat (naif) akan ketidakbergantungan dari masingmasing kondisi/kejadian. Berdasarkan (Utami, 2014) menerangkan bahwa Naive Bayes dalam setiap kelompok keputusan memiliki probabilitas sebagai syarat bahwa kelompok keputusan adalah benar berdasarkan informasi obyek. Proses algoritma ini mengindikasikan bahwa setiap atribut dalam obyek adalah tidak bergantung (independent). Probabilitas yang terlibat dalam memproduksi perkiraan akhir dihitung sebagai jumlah frekuensi dari master tabel keputusan. Naïve Bayes Classifier bekerja sangat baik dibanding dengan model classifier lainnya (Natalius dan Samuel, 2010). Keuntungan mengunakan metode Naïve Bayes Classifier adalah metode ini hanya memerlukan jumlah data training yang relatif kecil dalam menentukan perkiraan nilai parameter dalam proses identifikasi (Syaril, 2016). Asumsi independen naif tersebut menyebabkan ketentuan probabilitas menjadi lebih sederhana, hal ini menyebabkan proses perhitungan metode ini lebih mungkin untuk di lakukan. Seperti penjabaran $P\left(C \mid F_{1} \ldots F_{n}\right)$ dapat disederhanakan menjadi:

$$
\begin{aligned}
P\left(C \mid F_{1} \ldots F_{n}\right) & =P(C) P\left(F_{1} \mid C\right) P\left(F_{2} \mid C\right) P\left(F_{3} \mid C\right) \\
& =P(C) \prod_{i=1}^{n} P\left(F_{i} \mid C\right)
\end{aligned}
$$

Diharapkan dalam penelitian yang dilakukan identifikasi rumah tangga miskin dapat dilakukan dengan baik sehingga program pengentasan kemiskinan dapat tepat sasaran sesuai RTM yang membutuhkan.

\section{METODE}

Penelitian yang dilakukan menggunakan metode sistem dengan langkah-langkah sebagai berikut:

\section{A. Analisis}

Identifikasi RTM dengan tepat akan mempermudah dalam penyaluran berbagai bantuan program pengentasan kemiskinan bagi Dinas Sosial Kabupaten Tabanan. Dalam menentukan kemiskinan dari sebuah rumah tangga di Kabupaten Tabanan memiliki indikator keluarga non sejahtera (Badan Pusat Statistik Provinsi Bali, 2014) sebagai berikut:
1) Luas lantai rumah tinggal tidak lebih dari $8 \mathrm{~m}^{2}$

2) Jenis lantai rumah tinggal terbuat dari dari tanah/bambu/kayu

3) Jenis dinding rumah tinggal dari bambu/rumbia/kayu berkualitas rendah

4) Tidak memiliki fasilitas MCK (jamban/kakus)

5) Sumber pencahayaan keluarga bukan dari listrik

6) Konsumsi air minum dari mata air tak terlindungi/sungai/air hujan/sumur

7) Sumber untuk memasak sehari-hari dari kayu bakar/arang

8) Tidak mengkonsumsi daging/susu/ayam dalam satu minggu

9) Tidak mampu membeli sandang untuk setiap anggota keluarga dalam setahun

10) Frekuensi makan kurang dari tiga kali per hari untuk setiap ART

11) Tidak mampu berobat ke puskesmas/poliklinik

12) Lapangan pekerjaan utama kepala rumah tangga yaitu petani gurem/pekerja bebas dengan upah per bulan kurang dari Rp. 600.000

13) Pendidikan tertingi kepala rumah tangga sekolah dasar atau tidak pernah sekolah

14) Tidak bernilai lebih dari 500.000 .

Berdasarkan hasil pengamatan yang dilakukan terhadap beberapa permasalahan yang ditemukan dalam proses pendataan identifikasi rumah tangga, maka dapat ditentukan kebutuhan pengguna sistem sebagi berikut:

1) Dibutuhkan informasi tentang standarisasi dalam proses penilaian rumah tangga sehingga dapat ditentukan tingkat kemiskinan rumah tangga tersebut, dengan tujuan bahwa program pengentasan kemiskinan dapat disalurkan dengan tepat sasaran.

2) Informasi RTM dapat terekam dengan jelas baik periode saat ini maupun periode tahun-tahun yang sebelumnya

3) Pada proses penilaian terhadap rumah tangga dalam penelitian ini akan ditentukan tingkat Keluarga Sejahtera (KS) dari sebuah keluarga yaitu: keluarga pra sejahtera, keluarga sejahtera I, keluarga sejahtera II, 
keluarga sejahtera III, keluarga sejahtera III plus.

4) Laporan RTM hasil penilaian yang dilakukan oleh sistem.

Melalui kebutuhan pengguna maka ditentukan analisis kebutuhan fungsional dari sistem yang dibangun. Kebutuhan fungsional disajikan melalui Use Case dengan menyiapkan fungsi-fungsi yang diberikan oleh sebuah sistem informasi. Melalui kondisi tersebut yang ditekankan adalah apa yang dikerjakan sistem dan bukan bagaimana sistem itu mengerjalan proses. Use Case mengindikasikan sebuah hubungan antara pengguna dengan sistem. Adapun diagram Use Case pada gambar 1 dibawah.

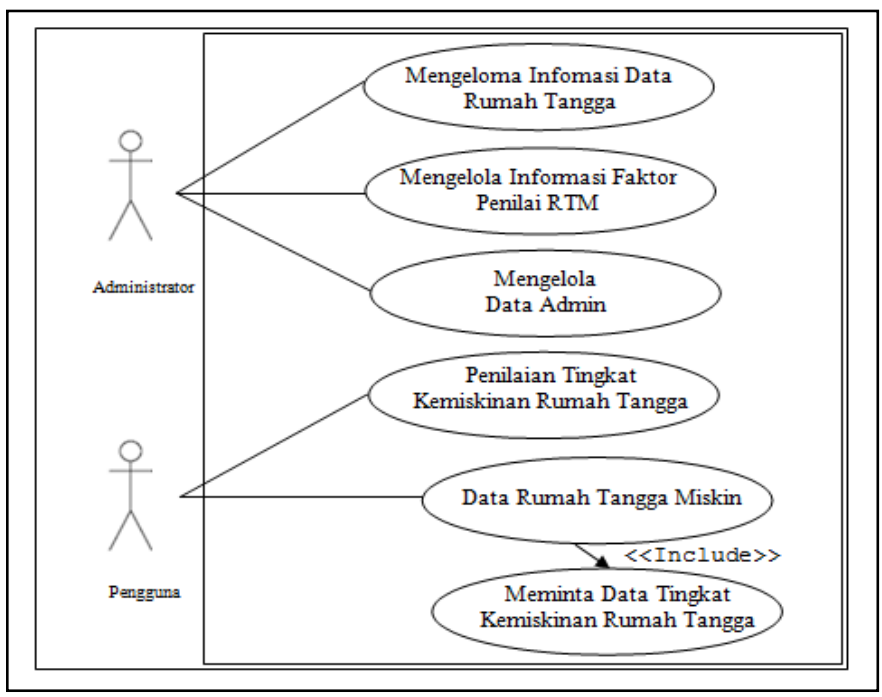

Gambar 1. Diagram Use Case Sistem Identifikasi Keluarga Miskin

Selanjutnya kebutuhan non-fungsional sistem merupakan kebutuhan yang harus dipenuhi agar aplikasi yang dibuat mendapat umpan balik yang baik dari pengguna aplikasi. adapun kebutuhan non-fungsional sistem antara lain:

- Performa: sistem harus mampu melakukan setiap perintah secara utuh dalam selang waktu yang tidak terlalu lama sesuai dengan ukuran data input yang diberikan.

- Informasi: Sistem harus mampu menyediakan informasi tentang data-data yang akan digunakan pada sistem.

- Ekonomi: Sistem harus dapat bekerja dengan baik tanpa harus mengeluarkan biaya tambahan yang tinggi.

- Kontrol: sistem yang sudah diimplementasikan harus tetap diawasi setelah selesai didesain sehingga fungsi serta kinerja sistem selalu siaga, hal ini dimaksudkan supaya hasil yang diberikan sesuai kebutuhan pengguna.

- Efisiensi: aplikasi harus di desain sesederhana mungkin supaya memberikan kemudahan bagi pengguna dalam menjalankan sistem tersebut.
- Pelayanan: aplikasi yang telah di desain dapat dikembangkan ke level yang lebih rumit lagi bagi pengembang sistem tersebut.

Untuk mengukur akurasi dari hasil pengujian dengan data uji menggunakan formula sebagai berikut:

$$
\text { Akurasi }=\frac{\sum \text { data uji benar }}{\sum \text { data uji }} \times 100 \%
$$

\section{B. Perancangan}

Tahap selanjutnya adalah perancangan setelah melalui tahapan analisis. Proses penilaian sebuah rumah tangga pada penelitian ini menggunakan model Naïve Bayes Classifier, dimana model ini digunakan untuk melakukan klasifikasi penentuan tingkat kesejahteraan rumah tangga berdasarkan indikator penilai kesejahteraan yang digunakan. Proses pada sistem untuk melakukan klasifikasi Naïve Bayes yaitu dengan membaca model data:

- Data training digunakan menentukan data yang akan di proses dengan algoritma Naive Bayes Classifier sehingga langkah awal yang akan dilakukan adalah 
membaca data latih. Data latih yang digunakan sebanyak 60 data latih.

- Data uji menggunakan data dari Desa Senganan, Kecamata Penebel, Kabupaten Tabanan. Data uji memiliki

- indikator berdasarkan faktor penilai dalam menentukan tingkat Kesejahteraan Keluarga.

Model identifikasi kesejahteraan keluarga dalam penelitian ini berdasarkan tingkat keluarga sejahtera memiliki algoritma sebagai berikut:

1. Baca data training

2. Proses learning

a. Hitung jumlah dan probabilitas yaitu dengan mencari angka probabilitas serta menghitung seluruh data yang sesuai dari katagori yang sama dibagi dengan jumlah data pada kategori tersebut.

b. Mendapatkan nilai dalam tabel probabilitas

3. Proses klasifikasi

a. Hasil kali posteriori probability dengan prior probability

b. Memeriksa kesesuaian untuk klasifikasi

\section{Selesai}

Aliran proses pada sistem identifikasi keluarga miskin dengan Naïve Bayes Classifier dijelaskan dengan flowchat dibawah ini.

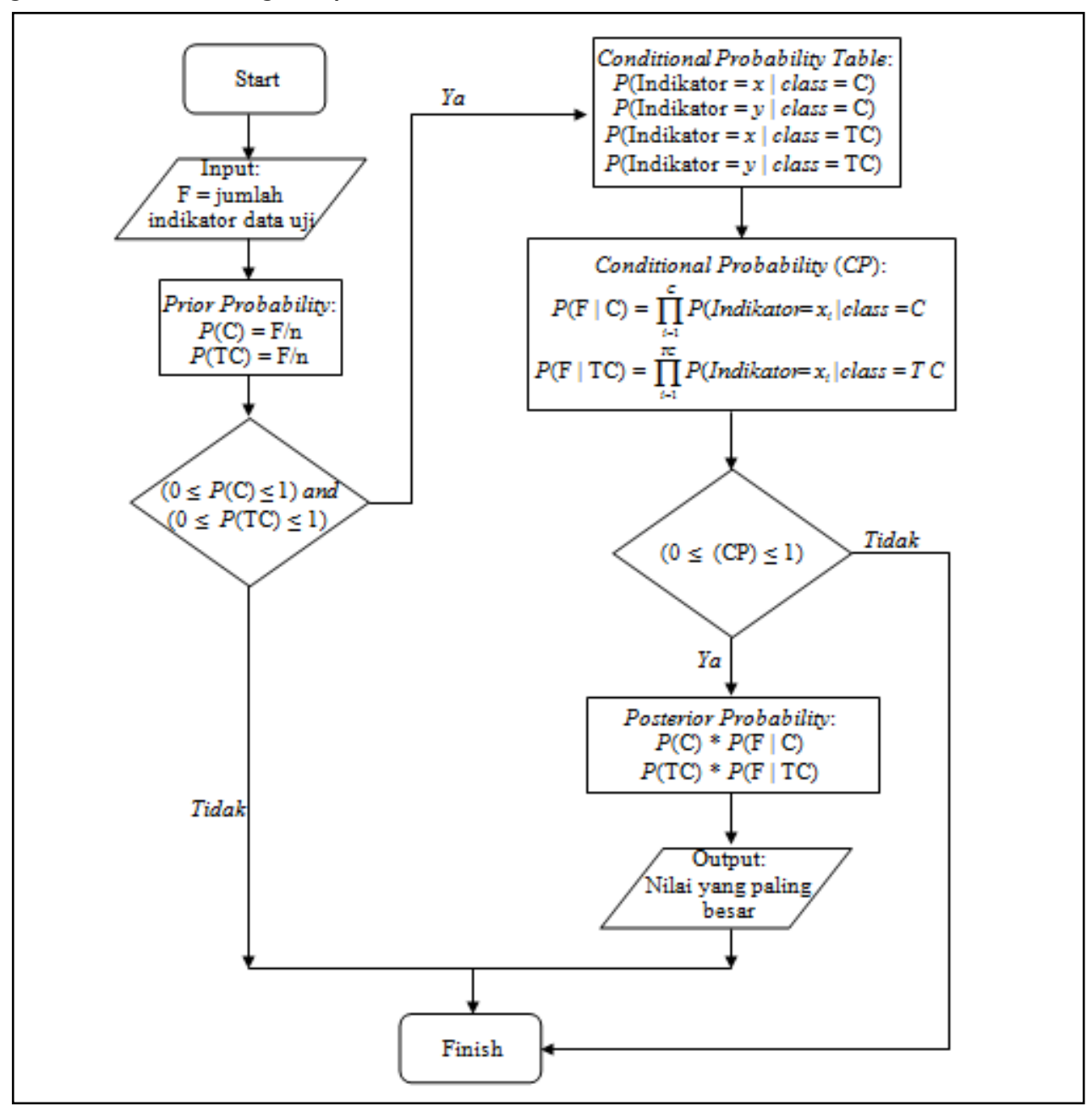

Gambar 2. Metode Naïve Bayes Classifier

Flowchat pada gambar 2 diatas menggambarkan proses klasifikasi data penduduk dengan Naïve Bayes Classifier dimana varibel $\mathrm{C}$ adalah cocok dan CT adalah variabel tidak cocok. Langkah pertama menentukan inputan berdasarkan indikator data uji dan menentukan prior probability, jika nilainya diluar dari 0 sampai 1 maka proses akan berhenti, jika tidak maka dilanjutkan dengan menentukan conditional probability table (CPT). CPT menghitung nilai probabilitas dari seluruh indikator berdasarkan jenis prior probability kemudian semua nilainya dikalikan, uji apakah nilai berada pada selang 0 sampai 1 jika tidak proses selesai dan jika ya maka proses 
dilanjutkan dengan menghitung perkalian antara prior probability dengan posterior probability untuk masing-masing $\mathrm{C}$ dan $\mathrm{CT}$.

kebutuhan pengguna sistem menunjukkan proses yang akan terjadi pada sistem yang dikembangkan melalui perancangan sistem berupa Data Flow Diagram (DFD). Pada gambar 3 dibawah ini menggambarkan proses awal adalah proses login untuk level user pengguna sistem yaitu administrator memiliki akses sebagai super user untuk semua proses yang ada dalam sistem. Level kedua adalah pengguna sistem yaitu petugas yang memiliki fungsionalitas untuk melakukan proses pendataan dan penilaian berdasarkan indikator sistem.
Hasil perkalian dari dua variabel tersebut yang lebih besar maka nilai itu adalah outputnya. Berdasarkan analisis

Proses kedua adalah simpan data rumah tangga yaitu menyimpan data dasar rumah tangga dan data indikator penilaian rumah tangga yang dilakukan oleh user administrator serta menyimpan nilai pendataan data dasar dan penilaian indikator oleh user petugas. Pada proses ketiga metode yaitu mengklasifikasikkan data rumah tangga dengan algoritma Naïve Bayes Classifier. Proses yang terakhir adalah menampilkan data laporan klasifikasi keluarga sejahtera

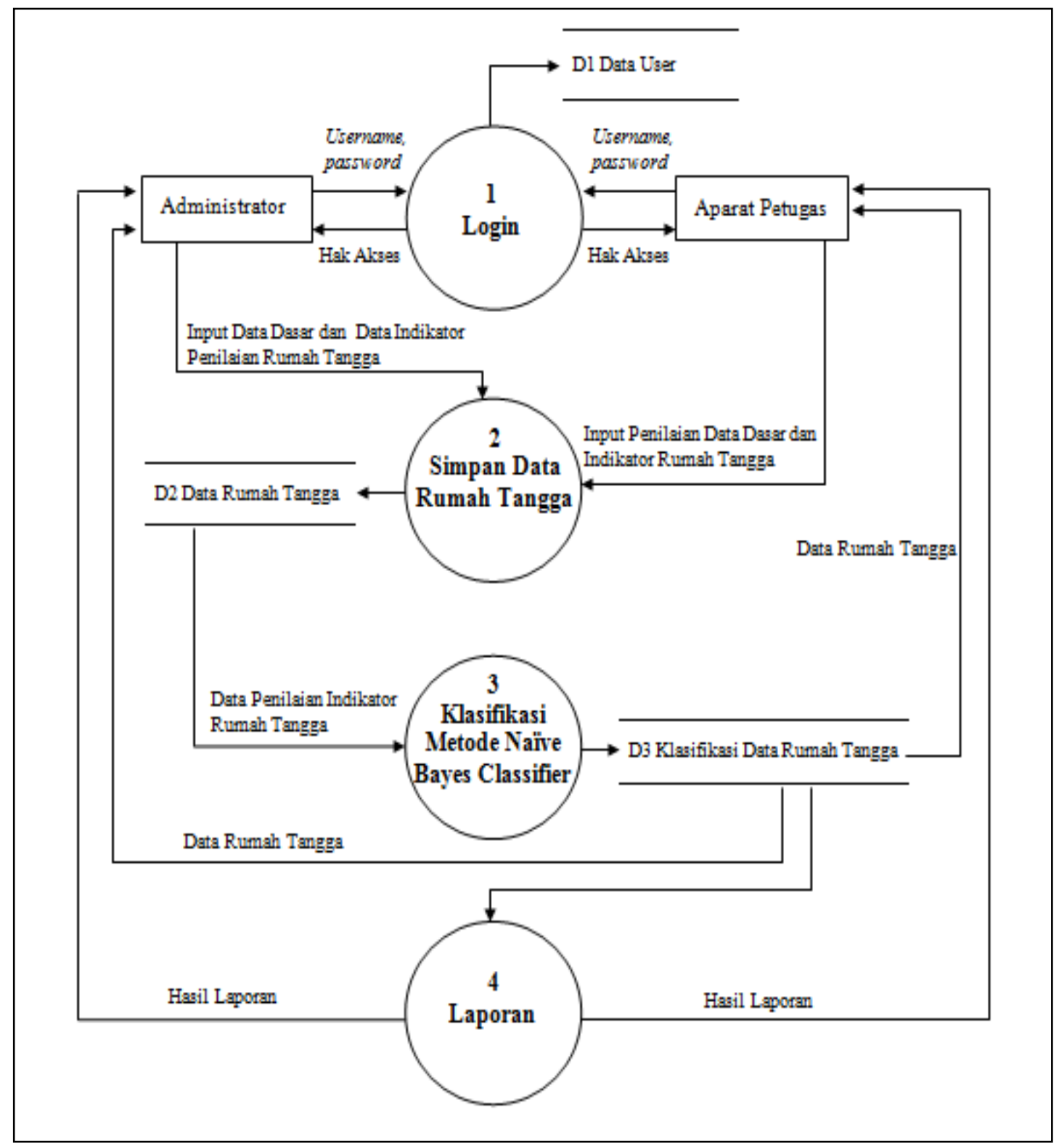

Gambar 3. Data Flow Diagram Level 1 
Selanjutnya rancangan Entity relationship diagram pada sistem identifikasi keluarga miskin, terdapat 6 entitas yang terlibat dalam relasi yaitu user, keluarga, indikator, indikator detail, data latih dan tingkat keluarga. ERD sistem disajikan pada gambar 4 dibawah.

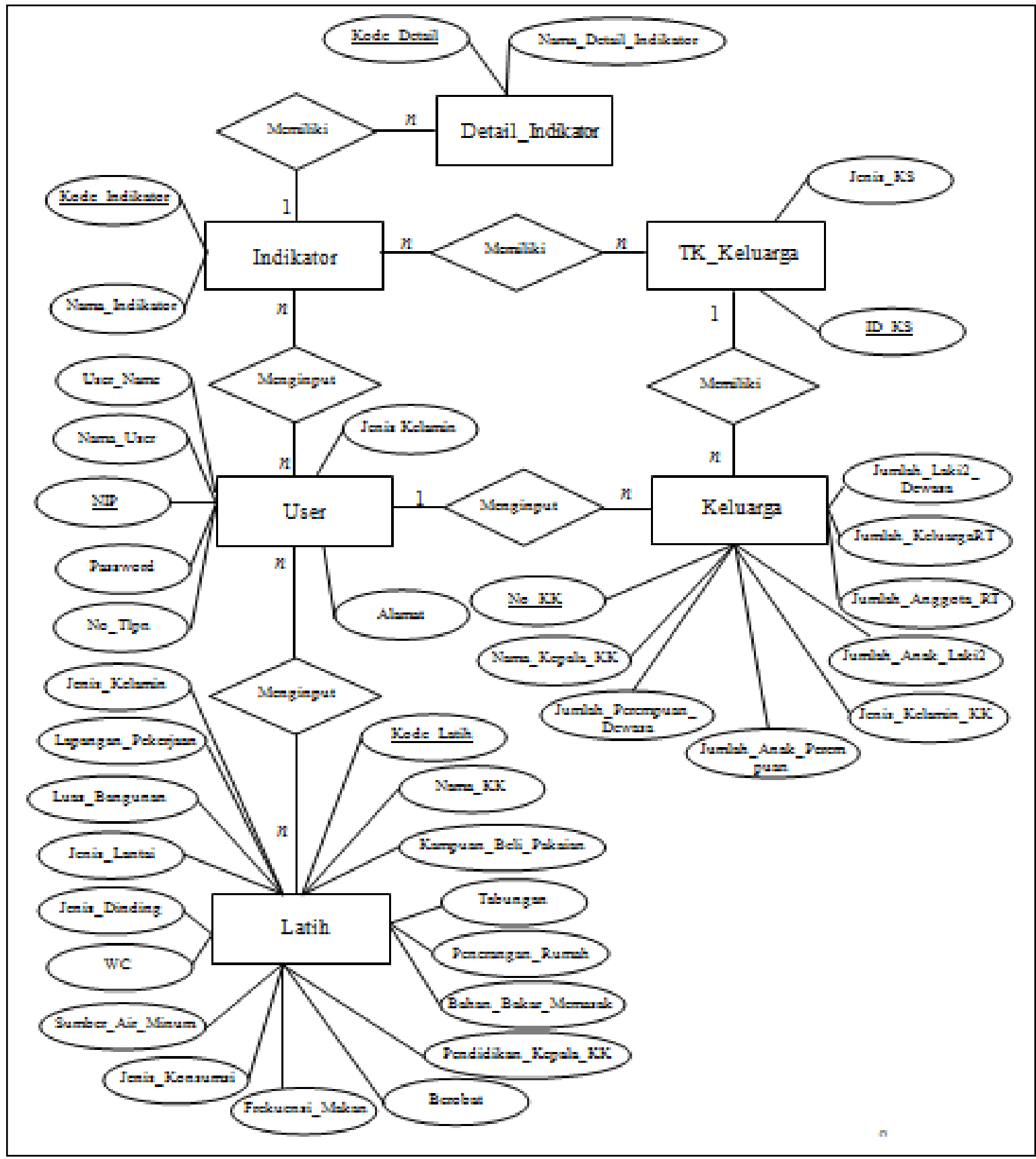

Gambar 4. Data Flow Diagram Level 1

\section{HASIL DAN PEMBAHASAN}

Pembahasan dari setiap tahapan penelitian diuraikan sebagai berikut:

\section{A. Hasil Tahap Analisis}

Pengembangan sistem identifikasi keluarga miskin menggunakan Naïve Bayes Classifier, yaitu pada proses pertama mendata data dasar rumah tangga untuk mengetahui identitas sebuah keluarga. Data yang di rekam pada proses ini adalah nomor kartu keluarga, nama kelapa keluarga, jenis kelamin kepala keluarga, jumlah anggota rumah tangga, jumlah keluarga dalam rumah tangga, jumlah laki-laki dewasa dalam rumah tangga, jumlah perempuan dewasa dalam rumah tangga, jumlah anak laki-laki dan jumlah anak perempuan. Semua keperluan 
data pada proses ini harus direkam dengan baik yang akan digunakan untuk memverifikasi rumah tangga sehingga dapat dilanjutkan proses klasifikasi.

Pada proses kedua dilakukan penilaian terhadap data rumah tangga yang sudah direkam. Setiap keluarga yang dinilai oleh sistem akan di klasifikasi salah satu dari empat kelas yang digunakan yaitu: Keluarga Pra Sejahtera, Keluarga Sejahtera Tingkat I, Keluarga Sejahtera Tingkat II, Keluarga Sejahter Tingkat III dan Keluarga Sejahtera Tingkat III Plus. Pada proses ini ada 14 indikator penilai sebuah keluarga untuk menentukan klasifikasinya seperti: luas lantai, jenis lantai, jenis dinding, toilet, sumber penerangan, sumber air, bahan bakar, konsumsi daging, pakaian, frekuansi makan, berobat, lapangan pekerjaan, pendidikan KK dan kepemilikan tabungan.

Berdasarkan data latih yang digunakan, maka akan di uji dengan melakukan perhitungan manual dari data inputan berupa: luas lantai $=$ kurang dari $8 \mathrm{~m}^{2}$, jenis lantai = bukan tanah, jenis dinding $=$ dinding batako, toilet $=$ toilet tidak standar MCK, sumber penerangan = listrik, sumber air = PDAM, bahan bakar = kayu, konsumsi daging = diatas seminggu, pakaian = pakaian baru setahun sekali, frekuensi makan $=3 \mathrm{kali}$ sehari, berobat = puskesmas, lapangan pekerjaan $\mathrm{KK}=$ pekerjaan serabutan, pendidikan $\mathrm{KK}=\mathrm{SD}$, tabungan = tidak memiliki aset. Berdasarkan metode Naïve Bayes Classifier yang digunakan maka klasifikasi data keluarga dapat ditentukan sebagai berikut:

1) Tingkat Keluarga Sejahtera adalah KPS

$=P\left(\right.$ Kurang dari $\left.8 \mathrm{~m}^{2} \mid \mathrm{KPS}\right){ }^{*} \mathrm{P}$ (Bukan Tanah | KPS) * $\mathrm{P}($ Batako | KPS) * $\mathrm{P}($ Toilet Tidak Standar MCK | KPS) * $\mathrm{P}($ Listrik | KPS) * $\mathrm{P}(\mathrm{PDAM} \mid \mathrm{KPS})$ * $P($ Kayu | KPS $){ }^{*} P($ Diatas Seminggu | KPS $)^{*} \quad P($ Pakaian Baru Setahun Sekali | KPS $){ }^{*} P(3$ Kali Sehari | KPS $)$ * $P($ Puskesmas | KPS) * P(Pekerjaan Serabutan | KPS) * P(SD | KPS) * $\mathrm{P}$ (Tidak Memiliki Aset | KPS)

$=0.93 * 0.47^{*} 0.27 * 0.53 * 0.40 * 0.60$ * $0.67 * 0.93 * 0.13 * 0.27 * 0.20$ * $0.73 * 0.27 * 0.53$

$=0.00000686$

2) Tingkat Keluarga Sejahtera adalah KS I $=\mathrm{P}\left(\right.$ Kurang dari $\left.8 \mathrm{~m}^{2} \mid \mathrm{KS} \mathrm{I}\right){ }^{*} \mathrm{P}($ Bukan Tanah |KS I) * $\mathrm{P}($ Batako | KS I) * $\mathrm{P}($ Toilet Tidak Standar MCK | KS I) *
$\mathrm{P}($ Listrik | KS I) * $\mathrm{P}(\mathrm{PDAM} \mid \mathrm{KS} \mathrm{I})$ * $P($ Kayu $\mid K S I){ }^{*} P($ Diatas Seminggu $\mid$ KS I)* P(Pakaian Baru Setahun Sekali | KS I) * P(3 Kali Sehari | KS I) * $P($ Puskesmas |KS I) * P(Pekerjaan Serabutan |KS I) * $P(S D \mid K S ~ I)$ * $\mathrm{P}$ (Tidak Memiliki Aset | KS I)

$=0.77 * 0.73 * 0.64 * 0.82 * 0.77 * 0.59$

* $0.73 * 0.91 * 0.36$ * 0.59 * 0.55 *

$0.55 * 0.32 * 0.59$

$=0.00108$

3) Tingkat Keluarga Sejahtera adalah KS II

$=P\left(\right.$ Kurang dari $\left.8 \mathrm{~m}^{2} \mid \mathrm{KS} \mathrm{II}\right){ }^{*} \mathrm{P}($ Bukan Tanah | KS II) * P(Batako | KS II) * P(Toilet Tidak Standar MCK | KS II) * $\mathrm{P}($ Listrik | KS II) * P(PDAM | KS II) * $P($ Kayu | KS II) * $P($ Diatas Seminggu | KS II)* P(Pakaian Baru Setahun Sekali | KS II) * P(3 Kali Sehari | KS II) * P(Puskesmas | KS II) * $\mathrm{P}($ Pekerjaan Serabutan | KS II) * $\mathrm{P}(\mathrm{SD} \mid \mathrm{KS}$ II) * $\mathrm{P}($ Tidak Memiliki Aset | $\mathrm{KS}$ II)

$=0.23 * 0.85 * 0.38 * 0.54 * 0.69 * 0.77$

* $0.15 * 0.23 * 0.23 * 0.54 * 0.69$ *

$0.31 * 0.23 * 0.08$

$=0.000000359$

4) Tingkat Keluarga Sejahtera adalah KS III

$=\mathrm{P}$ (Kurang dari $8 \mathrm{~m}^{2} \mid \mathrm{KS}$ III) * $\mathrm{P}$ (Bukan Tanah | KS III) * P(Batako | KS III) * P(Toilet Tidak Standar MCK I KS III) ${ }^{*} \mathrm{P}($ Listrik | KS III $){ }^{*} \mathrm{P}(\mathrm{PDAM} \mid$ KS III) * $\mathrm{P}($ Kayu | KS III $)$ * $\mathrm{P}$ (Diatas Seminggu | KS III) * P(Pakaian Baru Setahun Sekali | KS III) * P(3 Kali Sehari | KS III) * P(Puskesmas | KS III) * P(Pekerjaan Serabutan | KS III) * $\mathrm{P}(\mathrm{SD} \mid \mathrm{KS}$ III) * $\mathrm{P}$ (Tidak Memiliki Aset | KS III)

$=0.17 * 0.67 * 0.17 * 0.17 * 0.67 * 0.67$ * $0.17 * 0.33 * 0.33 * 0.33 * 0.67$ * $0.33 * 0.17 * 0.17$

$=0.000000058$

5) Tingkat Keluarga Sejahtera adalah KS III Plus

$=\mathrm{P}$ (Kurang dari $8 \mathrm{~m}^{2} \mid \mathrm{KS}$ III Plus) * P(Bukan Tanah | KS III Plus) * $\mathrm{P}$ (Batako | KS III Plus) * P(Toilet Tidak Standar MCK | KS III Plus) * $\mathrm{P}$ (Listrik | KS III Plus) * P(PDAM | KS III Plus) * $\mathrm{P}($ Kayu | KS III Plus) * $P\left(\right.$ Diatas Seminggu | KS III Plus) ${ }^{*}$ P(Pakaian Baru Setahun Sekali | KS III Plus) * P(3 Kali Sehari | KS III Plus) * P(Puskesmas | KS III Plus) * P(Pekerjaan Serabutan | KS III Plus) 


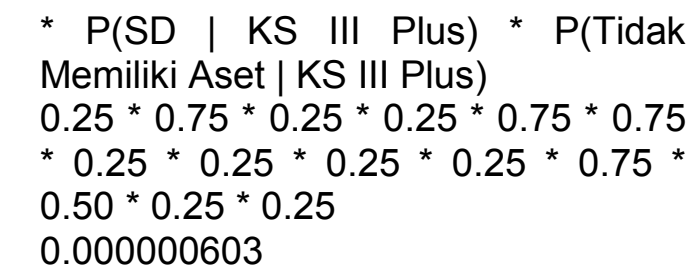

Bandingkan hasil probabilitas masingmasing kelas pada langkah diatas, terlihat bahwa nilai probabilitas kelas tertinggi ada pada kelas $\mathrm{P}($ Tingkat $\mathrm{KS}=\mathrm{KS} \mathrm{I})$ sehingga dapat disimpulkan bahwa status calon keluarga tersebut masuk dalam klasifikasi "Keluarga Sejahtera I".

B. Hasil Tahap Perancangan

Hasi proses penilaian dengan sistem terhadap perhitungan manual yang dilakukan dengan proses yang dihasilkan dalam sistem dapat disajikan pada gambar 5 dibawah ini.

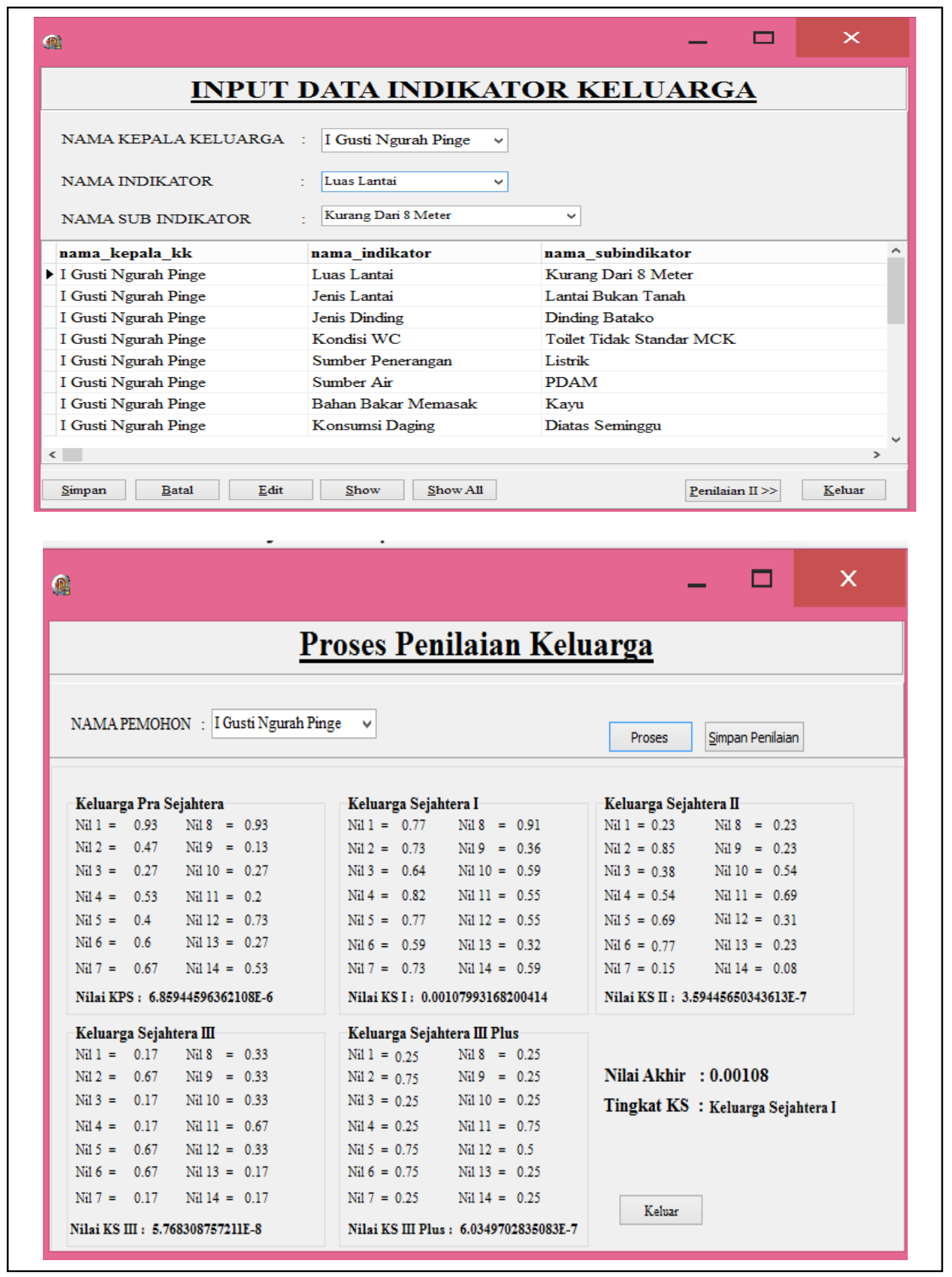

Gambar 5. Data Flow Diagram Level 1

Berdasarkan hasil perhitungan sistem dengan penilaian manual yang sudah dilakukan terlihat klasifikasi yang sama yaitu keluarga sejahtera I dengan nilai 0.00108 . 
Selanjutnya pengujian sistem dilakukan terhadap 11 sampel data rumah tangga di Desa Senganan. Adapun hasil pengujian sistem yang sudah dilakukan adalah sebagai berikut:

1) Keluarga Sang Wayan Guntur dari Banjar Keridan dengan hasil penilaian sistem yaitu keluarga pra sejahtera sebesar $1.683 \times 10^{-5}$, keluarga sejahtera I sebesar $3.188 \times 10^{-7}$, keluarga sejahtera II sebesar $2.188 \times 10^{-9}$, keluarga sejahtera III sebesar $7.209 \times 10^{-9}$, keluarga sejahtera III plus sebesar $1.341 \times 10^{-7}$. Nilai terbesar dari kelima penilaian tersebut menunjukkan bahwa keluaga ini berada pada tingkat keluarga pra sejahtera.

2) Keluarga I Ketut Antika dari Banjar Soka Kangin dengan hasil penilaian sistem yaitu keluarga pra sejahtera sebesar $6.646 \times 10^{-13}$, keluarga sejahtera I sebesar $2.670 \times 10^{-10}$, keluarga sejahtera II sebesar $2.512 \times 10^{-5}$, keluarga sejahtera III sebesar $3.167 \times 10^{-4}$, keluarga sejahtera III plus sebesar 8.799 $x 10^{-4}$. Nilai terbesar dari kelima penilaian tersebut menunjukkan bahwa keluaga ini berada pada tingkat keluarga sejahtera III plus.

3) Keluarga I Gusti Ngurah Pinge dari Banjar Bugbugan dengan hasil penilaian sistem keluarga pra sejahtera sebesar $6.859 \times 10^{-6}$, keluarga sejahtera I sebesar $1.079 \times 10^{-3}$, keluarga sejahtera II sebesar $3.594 \times 10^{-7}$, keluarga sejahtera III sebesar $5.768 \times 10^{-8}$, keluarga sejahtera III plus sebesar $6.035 \times 10^{-7}$. Nilai terbesar dari kelima penilaian tersebut menunjukkan bahwa keluaga ini berada pada tingkat keluarga sejahtera I.

4) Keluarga I Made Darma Yasa dari Banjar Bugbugan hasil penilaian sistem tidak dapat dilakukan hal ini disebabkan data dasar rumah tangga tidak lengkap yaitu data kartu tanda penduduk tidak ada atau hilang.

5) Keluarga I Made Patra dari Banjar Pagi dengan hasil penilaian sistem keluarga pra sejahtera sebesar $2.597 \times 10^{-7}$, keluarga sejahtera I sebesar $8.738 \times 10^{-5}$, keluarga sejahtera II sebesar $3.100 \times 10^{-}$ 6 , keluarga sejahtera III sebesar $1.387 \mathrm{x}$ $10^{-7}$, keluarga sejahtera III plus sebesar $1.207 \times 10^{-6}$. Nilai terbesar dari kelima penilaian tersebut menunjukkan bahwa keluaga ini berada pada tingkat keluarga sejahtera I.

6) Keluarga I Wayan Sukada dari Banjar Senganan Kangin dengan hasil penilaian sistem keluarga pra sejahtera sebesar $2.439 \times 10^{-10}$, keluarga sejahtera I sebesar $4.531 \times 10^{-7}$, keluarga sejahtera II sebesar $6.913 \times 10^{-5}$, keluarga sejahtera III sebesar $3.500 \times 10^{-5}$, keluarga sejahtera III plus sebesar 4.888 $\times 10^{-5}$. Nilai terbesar dari kelima penilaian tersebut menunjukkan bahwa keluaga ini berada pada tingkat keluarga sejahtera II.

7) Keluarga I Gusti Ngurah Budi dari Banjar Anyar hasil penilaian sistem tidak dapat dilakukan hal ini disebabkan data dasar rumah tangga tidak lengkap yaitu data kartu keluarga tidak ada atau tidak punya.

8) Keluarga I Nyoman Cadra dari Banjar Soka Kawan hasil penilaian sistem tidak dapat dilakukan hal ini disebabkan data dasar rumah tangga tidak lengkap yaitu data kartu tanda penduduk dan kartu keluarga tidak ada.

9) Keluarga I Made Susila Dana dari Banjar Senganan Kangin dengan hasil penilaian sistem keluarga pra sejahtera sebesar $2.458 \times 10^{-13}$, keluarga sejahtera । sebesar $3.933 \times 10^{-10}$, keluarga sejahtera II sebesar $1.607 \times 10^{-4}$, keluarga sejahtera III sebesar $6.430 \times 10^{-4}$, keluarga sejahtera III plus sebesar 8.799 $\times 10^{-4}$. Nilai terbesar dari kelima penilaian tersebut menunjukkan bahwa keluaga ini berada pada tingkat keluarga sejahtera III plus.

10) Keluarga I Ketut Suwena dari Banjar Senganan Kangin dengan hasil penilaian sistem keluarga pra sejahtera sebesar $2.684 \times 10^{-5}$, keluarga sejahtera I sebesar $4.772 \times 10^{-7}$, keluarga sejahtera II sebesar $5.916 \times 10^{-11}$, keluarga sejahtera III sebesar $4.398 \times 10^{-9}$, keluarga sejahtera III plus sebesar $2.235 \times 10^{-8}$. Nilai terbesar dari kelima penilaian tersebut menunjukkan bahwa keluaga ini berada pada tingkat keluarga pra sejahtera.

11) Keluarga I Nyoman Arka dari Banjar Senganan Kangin dengan hasil penilaian sistem keluarga pra sejahtera sebesar $9.481 \times 10^{-13}$, keluarga sejahtera । sebesar $2.578 \times 10^{-9}$, keluarga sejahtera II sebesar $3.774 \times 10^{-4}$, keluarga sejahtera III sebesar $4.244 \times 10^{-4}$, 
keluarga sejahtera III plus sebesar 2.933 $\times 10^{-4}$. Nilai terbesar dari kelima penilaian tersebut menunjukkan bahwa keluaga ini berada pada tingkat keluarga sejahtera III.
Dibawah ini adalah tabel penilaian keluarga oleh Dinas Sosial Kabupaten Tabanan.

Tabel 1. Data Penilaian Manual Rumah Tangga Dinas Sosial Kabupaten Tabanan

\begin{tabular}{|c|l|l|l|l|}
\hline No & \multicolumn{1}{|c|}{$\begin{array}{c}\text { Nama Kepala } \\
\text { Rumah Tangga }\end{array}$} & $\begin{array}{c}\text { Kelengkapan } \\
\text { Data Dasar RT }\end{array}$ & \multicolumn{1}{|c|}{ Alamat } & \multicolumn{1}{|c|}{$\begin{array}{c}\text { Hasil } \\
\text { Penilaian }\end{array}$} \\
\hline 1 & Sang Wayan Guntur & Lengkap & $\begin{array}{l}\text { Banjar } \\
\text { Keridan }\end{array}$ & $\begin{array}{l}\text { Keluarga Pra } \\
\text { Sejahter }\end{array}$ \\
\hline 2 & I Ketut Antika & Lengkap & $\begin{array}{l}\text { Banjar Soka } \\
\text { Kangin }\end{array}$ & $\begin{array}{l}\text { Keluarga } \\
\text { Sejahtera III } \\
\text { Plus }\end{array}$ \\
\hline 3 & $\begin{array}{l}\text { I Gusti Ngurah } \\
\text { Pinge }\end{array}$ & Lengkap & $\begin{array}{l}\text { Banjar } \\
\text { Bugbugan }\end{array}$ & $\begin{array}{l}\text { Keluarga } \\
\text { Sejahtera I }\end{array}$ \\
\hline 4 & I Made Darma Yasa & Tidak Lengkap & $\begin{array}{l}\text { Banjar } \\
\text { Bugbugan }\end{array}$ & $\begin{array}{l}\text { Keluarga } \\
\text { Sejahtera I }\end{array}$ \\
\hline 5 & I Made Patra & Lengkap & Banjar Pagi & $\begin{array}{l}\text { Keluarga } \\
\text { Sejahtera I }\end{array}$ \\
\hline 6 & I Wayan Sukada & Lengkap & $\begin{array}{l}\text { Banjar } \\
\text { Senganan }\end{array}$ & $\begin{array}{l}\text { Keluarga } \\
\text { Sejahtera II }\end{array}$ \\
\hline 7 & $\begin{array}{l}\text { I Gusti Ngurah } \\
\text { Budai }\end{array}$ & Tidak Lengkap & $\begin{array}{l}\text { Banjar } \\
\text { Anyar }\end{array}$ & $\begin{array}{l}\text { Keluarga } \\
\text { Sejahtera II }\end{array}$ \\
\hline 8 & I Nyoman Candra & Tidak Lengkap & $\begin{array}{l}\text { Bajar Soka } \\
\text { Kawan }\end{array}$ & $\begin{array}{l}\text { Keluarga } \\
\text { Sejahtera I }\end{array}$ \\
\hline 9 & I Made Susila Dana & Lengkap & $\begin{array}{l}\text { Banjar } \\
\text { Senganan } \\
\text { Kangin }\end{array}$ & $\begin{array}{l}\text { Keluarga } \\
\text { Sejahtera III } \\
\text { Plus }\end{array}$ \\
\hline 10 & I Ketut Suwena & Lengkap & $\begin{array}{l}\text { Bajar } \\
\text { Senganan } \\
\text { Kangin }\end{array}$ & $\begin{array}{l}\text { Keluaga Pra } \\
\text { Sejahtera }\end{array}$ \\
\hline 11 & I Nyoman Arka & Lengkap & $\begin{array}{l}\text { Banjar } \\
\text { Senganan } \\
\text { Kangin }\end{array}$ & $\begin{array}{l}\text { Keluarga } \\
\text { Sejahtera III }\end{array}$ \\
\hline
\end{tabular}

Berdasarkan hasil pengujian sistem yang sudah dilakukan dan apabila dibandingkan dengan data penilaian Dinas Sosial Kabupaten Tabanan terlihat bahwa penilaian kelayakan dari sistem mendekati dari data penilaian Dinas Sosial. 11 data di identifikasi oleh sistem dengan 3 perbedaan data penilaian dari data Dinas Sosial, sehingga jika dihitung akuransinya dari data pengujian sistem

$$
\text { Akurasi }=\frac{8}{11}=0.72 \times 100 \%=72 \%
$$

kesesuai pengujian sistem dengan manual memiliki akurasinya sebesar $72 \%$.

\section{SIMPULAN}

Berdasarkan penelitian yang sudah dilakukan, maka dapat diambil kesimpulan sebagai berikut:

- Analisis dan pemodelan sistem identifikasi keluarga miskin dapat dilakukan perancangannya berdasarkan faktor-faktor penilai kemiskinan di Kabupaten Tabanan

- Metode Naïve Bayes Classifier dapat di terapkan dan mampu mengidentifikasi kelas rumah tangga dari indikator penilai sebesar $72 \%$.

- Penilaian dengan menggunakan metode Naïve Bayes Classifier menggabungkan penilaian-penilaian dan nilai-nilai kedalam suatu cara logis, tetapi tingkat objektivitas penilaian akan sangat tergantung pada imajinasi, naluri, pengalaman, pengetahuan dan pemahaman seseorang terhadap suatu masalah. 


\section{UCAPAN TERIMAKASIH}

Ucapan terimakasih disampaikan Universitas Dhyana Pura melalui Lembaga Penelitian dan Pengabdian Kepada Masyarakat dan Fakultas IImu Keshatan, Sains dan Teknologi Universitas Dhyana Pura yang telah membiayai pelaksanaan penelitian ini.

\section{DAFTAR PUSTAKA}

Badan Pusat Statistik Provinsi Bali, 2014. Sekretariat Komite Penanggulangan Kemiskinan Republik Indonesia. Denpasar.

Badan Pusat Statistik Bali, 2016. Sekretariat Komite Penanggulangan Kemiskinan Republik Indonesia. Denpasar.

Kendall, K.E. dan Kendall, J.E. 2006. Analisis dan Perancangan Sistem Informasi. Versi Bahasa Indonesia. Edisi Kelima. Jilid I. PT. Indeks Kelompok Gramedia. Jakarta.

Kusumadewi, Sri, 2009. Klasifikasi Status Gizi Menggunakan Algoritma Naïve Bayes Classification, Jurusan Teknik Informatika, Universitas Islam Indonesia

Natalius, Samuel, 2010. Metode Naïve Bayes Classifier dan Penggunaannya Pada Klasifikasi Dokumen, Program Studi Sistem dan Teknologi Informasi, Sekolah Teknik Elektro dan Informatika, Institut Teknologi Bandung.

Syaril, 2016. Metode Naïve Bayes Untuk Prediksi Kelulusan (Studi Kasus: Data Mahasiswa Baru Perguruan Tinggi). Jurnal IImiah IImu Komputer. Volume 2 No 1, April 2016

Utami, D. K, Kusuma. W.A, dan Buono. A 2014. Klasifikasi Metagenom Dengan Metode Naïve Bayes Classifier Metagenom Classifier Using Naïve Bayes Classfier Methos. Jurnal IImu Komputer Agri Informatika. Volume 3 Nomor $1 \mathrm{Hal} \mathrm{9-18.}$ 